УДК 341: 343.3

DOI https:// doi.org/10.32837/yuv.v0i4.1982

\title{
T. Сергеєва,
}

кандидат юридичних наук, доцент кафедри правоохоронної та антикорупційної діяльності Навчально-наукового інституту права

Міжрегіональної Академії управління персоналом

\section{ЗАПРОВАДЖЕННЯ МІЖНАРОДНИХ АНТИКОРУПЦІЙНИХ СТАНДАРТІВ У НАЦІОНАЛЬНЕ ЗАКОНОДАВСТВО УКРАЇНИ}

Існування корупції в суспільстві свідчить про те, що вона задовольняе певні потреби суспільної системи, відіграє специфічну роль в іiі підтриманні як єдиного цілого. 3 цього боку корупція пов'язана не лише з вадами суспільства, недосконалістю людської природи, а також із низькими моральними якостями носіїв корупційних відносин. Вона зумовлена також тим, що формальні, закріплені нормативно моделі відносин між державними й приватними суб'єктами не можуть забезпечити повноцінного функціонування системи й тому об'єктивно доповнюються неформальними відносинами. Специфічною формою цих відносин і є корупція.

Україна зазнає тих самих негативних наслідків від корупції, що й інші країни. Усвідомлення того, наскільки деструктивно корупція впливає на розвиток суспільства, спонукає нашу державу до активної боротьби 3 корупцією та тісніше міжнародне співробітництво в цій сфері. Зовнішнім стимулом подолання корупції $€$ необхідність підвищення іміджу України на міжнародній арені. Водночас внутрішнім стимулом $€$ прагнення забезпечити стабільний розвиток національної економіки. Очевидний той факт, що обсяги залучення іно- земних інвестицій $€$ обернено пропорційними до рівня корумпованості держав. Так, оцінка міжнародних експертів має значний вплив на привабливість національної економіки держави для іноземних інвесторів.

Проблема боротьби з корупцією в різних їі проявах вже багато років не припиняє хвилювати світ. Цього питання торкається не мала кількість науковців, які, досліджуючи його, намагаються знайти причини й способи подолання цього шкідливого явища. Слід зазначити, що окремі теоретичні й практичні аспекти боротьби 3 корупцією представлені в працях таких вчених, як Л. Астаф'єв, M. Буроменський, К. Вишневська, А. Гайдук, Д. Заброда, О. Медвецька, М. Мельник, О. Прохоренко й інших. Недарма така тема роками залишається актуальною.

Мета статті - аналіз положень міжнародних угод щодо протидіï корупції та імплементація норм у законодавство України.

У сфері боротьби 3 корупцією Україна співпрацює з рядом міжнародних організацій, насамперед із Радою Європи й структурами Організації Об’єднаних Націй, зокрема Управлінням $\mathrm{OOH}$ із наркотиків і злочинності, на яке нині покладені 
функції Секретаріату Конвенції ООН проти корупції. Україна приєдналася до Конвенції ООН проти корупції 12 грудня 2003 р.

Механізм взаємного огляду державами-учасницями стану виконання зобов'язань за Конвенцією ООН проти корупції почав діяти у 2010 році. Україну було обрано одним із перших об'єктів такого огляду. Шляхом жеребкування було визначено, що зазначений огляд у нашій країні будуть проводити експерти з Польщі й Словенії. 3 української сторони в процесі огляду стану виконання конвенції брали участь експерти 3 ряду державних установ, зокрема Міністерства юстиції, Служби безпеки, Генеральної прокуратури й інших. Крім того, українські експерти дали свою оцінку стану виконання положень Конвенції разом із супровідними матеріалами й поясненнями [1].

Участь у першій хвилі механізму огляду стану виконання Конвенції $\mathrm{OOH}$ дала можливість Україні на практиці здійснити ревізію національного антикорупційного законодавства, отримати інформацію про досвід інших країн-учасниць Конвенції в їх кроках із подолання корупції, а також визначити потреби, які має наша країна в технічній допомозі з метою подальшої імплементації положень Конвенції.

Україна й інші держави, які беруть участь у реалізації Стамбульського плану Організації економічного співробітництва й розвитку, висловили свою згоду здійснювати його положення задля сприяння розвитку, економічному зростанню та соціальній стабільності.

Рада Європи розробила кілька міжнародно-правових документів у цій сфері: Кримінальну Конвенцію Ради Європи про боротьбу 3 корупцією 1999 р., Цивільну Конвенцію Ради Європи про боротьбу з корупцією 1999 р., Двадцять принципів боротьби з корупцією 1997 р., Модельний кодекс поведінки для державних службовців 2000 р., Єдині правила протидії корупції під час фінансування політичних партій і виборчих кампаній 2003 р. Контроль за реалізацією зазначених документів покладено на Групу держав Ради Європи проти корупції (далі - ГРЕКО).

Приєднання до Цивільної конвенції Ради Європи про боротьбу з корупцією зробило Україну сороковим членом Групи держав Ради Європи проти корупції. Приєднавшись до цього міжнародного інструменту, Україна взяла на себе зобов'язання брати участь у процесах взаємного оцінювання щодо виконання антикорупційних рекомендацій цієї міжнародної організації. Раунди оцінювання, що вже були проведені, стосувалися діяльності спеціальних органів із боротьби 3 корупцією, імунітету посадових осіб щодо кримінального переслідування, попередження корупції в системі державного управління.

У зв'язку з набуттям для України чинності Цивільної конвенції Ради Європи про боротьбу з корупцією з 1 січня 2006 р. Україна стала сороковим членом ГРЕКО.

Приєднавшись до ГРЕКО, Україна зобов'язалась брати участь у процесі взаємної оцінки в рамках Групи. У травні 2009 р. на пленарному засіданні ГРЕКО затверджено звіт щодо виконання Україною антикорупційних рекомендацій цієї міжнародної організації. Ці рекомендації надано Україні за результатами першого й другого раундів оцінки. Зазначені раунди оцінки були присвячені діяльності спеціалізованих органів, які займаються запобіганням корупції, питанням імунітету посадових осіб щодо кримінального переслідування, а також питанням виявлення, вилучення та конфіскації доходів та іншого майна, отриманих внаслідок корупції, попередження корупції в системі держаного управління, відповідальності юридичних осіб за корупційні злочини.

Нині триває Третій раунд оцінювання України. У його рамках 
у квітні 2011 р. відбувся візит експертів ГРЕКО до України, в ході якого вивчалася ситуація стосовно імплементації в українське законодавство положень Кримінальної конвенції про боротьбу з корупцією та Додаткового протоколу до неї, а також рекомендацій Ради Європи щодо фінансування політичних партій. Заслуховування та затвердження звіту за результатами зазначеного оцінювання заплановано під час пленарної сесії ГРЕКО в жовтні 2011 р. [2].

Аналогічний механізм взаємної оцінки використовується для контролю за дотриманням та імплементацією положень Конвенції ООН проти корупції. Відповідно до графіка проведення оцінювання, Україна є однією з перших країн, щодо якої проводиться оцінка стану імплементації згаданої Конвенції ООН.

Крім того, Україна бере участь у зовнішньополітичній ініціативі держав-членів Європейського Союзу (далі - ЄС) «Східне партнерство», яку було започатковано у 2009 р. задля зміцнення стосунків зі східними сусідами $\in C$ та яка $є$ продовженням східного напрямку наявної Європейської політики сусідства.

3 метою виконання та імплементації норм міжнародного права щодо протидії корупції в Україні впроваджується та вдосконалюється власна система антикорупційного законодавства.

Антикорупційне законодавство України розвивається з урахуванням міжнародних зобов'язань, а також найкращих практик міжнародних регіональних та універсальних організацій. 3 урахуванням положень зазначених інструментів відбувається поступова імплементація до нашого правового поля різних міжнародних документів.

Рівень протидії корупції є одним із визначальних факторів, що характеризує державу як територію 3 високим рівнем економічної захищеності господарської діяльності, захищеності держави від зловживання службовим становищем державними службовцями під час виконання службових обов'язків, високим рівнем свободи здійснення підприємницької діяльності й сприятливим середовищем для інвестування. Бажання України вийти на світові ринки обміну товарів і послуг і міжнародні інтеграційні процеси повинні спонукати ії до покращення як внутрішнього національного законодавства, так і імплементації міжнародно-правових актів [3].

Базовою складовою частиною успішної протидії корупційним проявам $€$ належне антикорупційне законодавство. У вузькому розумінні антикорупційне законодавство - це закони й інші нормативно-правові акти, які встановлюють спеціальні законодавчі положення щодо запобігання корупції, визначають ознаки корупційних правопорушень і відповідальність за їх вчинення, регулюють діяльність державних органів чи їх спеціальних підрозділів, до компетенції яких належить протидія корупції, координація такої діяльності (контроль) і нагляд за нею [4].

Суть антикорупційного законодавства насамперед полягає в тому, щоб: по-перше, обмежити, нейтралізувати чи усунути чинники корупціï, запобігти конфліктам інтересів (з особистих і службових підстав), на нормативному рівні - визначити межі правомірної та етичної поведінки особи, уповноваженої на виконання функцій держави, зробити вчинення корупційних правопорушень справою невигідною та ризикованою, врешті, досягти того, щоб особа чесно й сумлінно виконувала свої службові обов'язки; по-друге, чітко визначити ознаки корупційних правопорушень, передбачити адекватні заходи відповідальності за їх вчинення, належним чином врегулювати діяльність органів державної влади та їх окремих підрозділів, що безпосередньо протидіють корупції [5, с. 104].

Аналіз чинного національного законодавства України свідчить, що

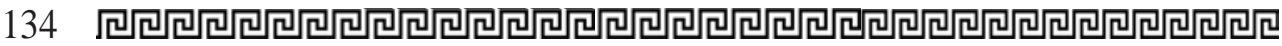


в державі існує та продовжує удосконалюватися нормативно-правова база, спрямована на протидію корупціi. В основі будь-якого нормативно-правового акта України лежить Конституція. Загальними основами законодавства України, визначеними в Конституції України, є принципи правової держави, верховенства права й дотримання приписів міжнародного права (ст. ст. $1,8,9,18)$ [6]. Такі принципи насамперед відповідають прагненням України створити сприятливе правове середовище як для власних громадян, так і для іноземців, і покращити свій імідж на міжнародній арені.

Основою для протидії корупції, зокрема у сфері здійснення підприємницької діяльності, є принцип «свободи підприємницької діяльності», закріплений у ст. 42 [6]. В основу цього принципу покладено свободу кожного громадянина займатися будь-якою підприємницькою діяльністю, крім тієї, що заборонена або обмежена законодавством. Такі відносини характеризуються переказними правами й обов'язками між державою в особі органів державної влади й суб'єктами підприємницької діяльності.

Створення сприятливого середовища для ведення підприємницької діяльності містить наділення кожного підприємця можливостями добросовісно виконувати свої обов'язки перед державою, водночас отримувати різнопланову допомогу 3 боку органів державної влади щодо ведення підприємницької діяльності, а також забезпечення кожного підприємця рівними правами й обов'язками.

Важливою передумовою для здійснення цього принципу є добросовісне виконання приписів антикорупційного законодавства всіма суб'єктами різних видів правовідносин.

Таким чином, можна зробити висновок, що Конституція України створює базис та окреслює основи антикорупційного законодавства, що втілюються у вигляді нових нормативно-правових актів у цій сфері. Крім того, Конституція закріплює зобов'язання держави й кожного громадянина дотримуватися норм міжнародного права.

Закони й підзаконні акти в цій сфері значним чином модернізовано внаслідок системного міжнародного впливу на Україну з приводу впровадження антикорупційних заходів. Особливо інтенсивним виявився період 2014-2015 рр., коли було ухвалено ряд законів, що містили новаторські для правової системи антикорупційні механізми: «Про запобігання корупції», «Про Національне антикорупційне бюро України», «Про прокуратуру», «Про внесення змін до деяких законодавчих актів України щодо забезпече'ння діяльності Національного антикорупційного бюро України та Національного агентства з питань запобігання корупції, «Про публічні закупівлі» тощо [7, с. 23-24].

Окремий блок складають закони, якими вдосконалено адміністративну й кримінальну відповідальність за корупційні правопорушення: «Про внесення змін до деяких законодавчих актів України щодо приведення національного законодавства у відповідність із стандартами Кримінальної конвенції про боротьбу з корупцією», «Про внесення змін до Кримінального та Кримінального процесуального кодексів України стосовно виконання Плану дій щодо лібералізації Європейським Союзом візового режиму для України», «Про внесення змін до деяких законодавчих актів України (щодо виконання Плану дій щодо лібералізації Європейським Союзом візового режиму для України стосовно відповідальності юридичних осіб)», «Про внесення змін до деяких законодавчих актів України щодо удосконалення законодавства у сфері запобігання і протидії корупції [8].

Стан імплементації Україною антикорупційних стандартів перебуває під постійною увагою відповідних міжна- 
родних інституцій, які за наслідками моніторингу готують регулярні звіти, де відзначається ступінь прогресу виконання наданих рекомендацій i, в разі потреби, надаються додаткові або уточнені рекомендації.

На виконання рекомендацій Європейської комісії щодо удосконалення процедури конфіскації майна ухвалено Закон «Про внесення змін до Кримінального та Кримінального процесуального кодексів України щодо виконання рекомендацій, які містяться у шостій доповіді Європейської комісії про стан виконання Україною Плану дій щодо лібералізації Європейським Союзом візового режиму для України, стосовно удосконалення процедури арешту майна та інституту спеціальної конфіскації» від 18 лютого 2016 р. [9].

Однією з найважливіших проблем антикорупційної політики України є іiі несистемність і відсутність методологічної бази.

3 початку 2018 р. в Україні відсутня Антикорупційна стратегія комплексний документ загальнодержавного рівня, який визначає заходи iз запобігання та протидії корупції. Без цього антикорупційні заходи були здебільшого несистемними й нескоординованими. Проєкт Антикорупційної стратегії, підготовлений Національним агентством із питань запобігання корупції, був розкритикований громадськістю, отримав значну кількість зауважень від національних і міжнародних експертів, а профільний парламентський комітет рекомендував Верховній Раді України відхилити його.

Виходячи 3 найкращого досвіду зарубіжних країн щодо створення дієвого національного механізму протидіiі корупції, варто створити в Україні єдиний централізований орган із боротьби 3 корупцією. Його створення дозволить уникнути дублювання функцій ряду державних органів із протидіі корупції, що $є$ однією iз суттєвих помилок побудови укра- їнської інституційної антикорупційної системи.

Крім того, на нашу думку, доцільно, щоб такий орган займався, серед іншого, питаннями розслідування фактів корупціі, ускладнених іноземним елементом. Саме такий вид корупції $€$ найскладнішим із боку можливості його розслідування та покарання винних осіб і тому потребує окремої уваги законодавця.

Таким чином, діяльність із реформування національного антикорупційного законодавства має відбуватися з урахуванням міжнародних зобов'язань України, а також 3 урахуванням зарубіжної практики. Водночас виконання будь-яких міжнародних зобов'язань у цілому й у сфері протидії корупції зокрема насамперед залежить від рівня правосвідомості в державі.

Стаття присвячена дослідженню законодавства України у сфеpi протидіï корупціi. Виявлено, що чинне законодавство лише частково враховує положення міжнародних антикорупційних договорів, стороною яких є Україна. Ряд питань залишаються лише частково врегульованими або взагалі неврегульованими. Зазначено, що корупиія деструктивно впливае на розвиток суспільства. Спонукае нашу країну до активної боротьби з корупиією здійснення міжнародного співробітництва у цүій сфеpi. Зроблено акцент на співпраці України з Радою Європи й структурами організації Об’єднаних Націй у сфері боротьби з корупцією. Підкреслено значення для України Цивільної конвенції Ради Європи про боротьбу з корупиією та проаналізовано основні моменти виконання Україною положень міжнародної угоди. Зазначено, що з метою виконання та імплементаціі норм міжнародного права щзоо протидіï корупції в Україні впроваджуеться та вдосконалюеться 
власна система антикорупційного законодавства.

Проаналізовано норми щодо вдосконалення адміністративної та кримінальної відповідальності за корупційні правопорушення. Закони й підзаконні акти в иүй сфері значним чином зазнали змін внаслідок міжнародного впливу на Україну міжнародних організацій із приводу впровадження антикорупційнх заходів та іх виконання.

Приділено увагу захищеності господарської діяльності й створенню сприятливого середовища для ведення підприємницької діяльності у світлі добросовісного виконання приписів антикорупційного законодавства всіма суб'єктами різних видів правовідносин.

Запропоновано використати досвід зарубіжних країн щуодо створення дієвого національного механізму протидії корупції. Варто створити в Україні єдиний иентралізований орган із боротьби з корупцією, який не дублюватиме функції ряду державних органів із протидіi корупції. Доцільно, щзоб такий орган займався питаннями розслідування фактів корупціі, ускладнених іноземним елементом. Зазначено, що нині українське антикорупційне законодавство ще має бути переглянуте у світлі базових положень міжнародних документів, шо удосконалить чинне законодавство.

Ключові слова: корупція, міжнародно-правовий механізм, міжнародне співробітництво, антикорупційне законодавство, імплементація.

Serhieieva T. International anticorruption standards and national legislation of Ukraine

The article is devoted to the study of Ukrainian legislation in the field of anti-corruption. It was found that the current legislation only partially takes into account the provisions of international anti-corruption agreements to which Ukraine is a party. A number of issues remain only partially settled or not settled at all. It is noted that corruption has a destructive effect on the development of society. Encourages our country to actively fight corruption, in particular, through international cooperation in this area. Emphasis is placed on Ukraine's cooperation with the Council of Europe and United Nations structures in the fight against corruption. The importance of the Council of Europe Civil Convention against Corruption for Ukraine was emphasized and the main points of Ukraine's implementation of the provisions of the international agreement were analyzed. It is noted that in order to implement and enforce the norms of international law on combating corruption in Ukraine, its own system of anti-corruption legislation is being introduced and improved.

The norms on improving administrative and criminal liability for corruption offenses are analyzed. Laws and by-laws in this area have undergone significant changes due to the international influence of international organizations on Ukraine regarding the implementation of anti-corruption measures and their implementation.

Attention is paid to the protection of economic activity and the creation of a favorable environment for doing business in the light of conscientious compliance with the requirements of anti-corruption legislation by all parties to various types of legal relations.

It is proposed to use the experience of foreign countries to create an effective national mechanism for combating corruption. It is necessary to create a single centralized anticorruption body in Ukraine, which will not duplicate the functions of a number of state anti-corruption bodies. It is advisable that such a body 


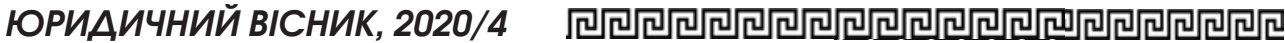

should deal with the investigation of corruption complicated by a foreign element. It is noted that today the Ukrainian anti-corruption legislation has yet to be revised in the light of the basic provisions of international documents, which will improve the current legislation.

Key words: corruption, international legal mechanism, international cooperation, anti-corruption legislation, implementation.

\section{Література}

1. Здійснення Конвениї організації Об'єднаних Націй проти корупції - оцінка громадянського суспільства: стенограма засідання круглого столу у Комітеті Верховної Ради України з питань боротьби з організованою злочинністю $i$ корупцією від 07 грудня 2011 p. URL: http:// crimecor.rada.gov.ua/komzloch/control/ uk/publish/ article?art_id $=48405 \&$ cat_ $i d=46352 \&$ showHidden $=1 \quad$ (дата звернення: 19.04.2020)

2. Участь України в міжнародному співробітництві у сфері запобігання та nротидiï корупuіï. URL: https: / / minjust. gov.ua/m/str_35749 (дата звернення: 19.04.2020)

3. Медвецька О.О. Поняття, ознаки та види корупиійних злочинів, їх особливості відповідно до актів міжнародного законодавства. Підприємництво, господарство і право. 2015. № 7. С. 42-48.

4. Прохоренко О.Я. Протидія корупиійним проявам у системі державноі служби України: організащійно-правовий аспект. Київ, 2004. 206 с.

5. Мамзин А.С., Рожин В.П. О законах функиионирования и законах развития. Вопросы философии. 1965. № 4. С. 3-8.

6. Конституція України: Закон України від 28 червня 1996 р. № 254к/96-BP / Верховна Рада України. URL: http:// zakon.nau.ua / doc/?code $=254 \% E A / 96$ \% C2\% DO (дата звернення: 20.08.2020).

7. Вишневська К.О. Iмплементація міжнародних антикорупційних стандартів у національне законодавство України. Право і суспільство. 2015. № 5.2. C. 22-28.

8. Антикорупиійний портал. URL: http://www.acrc.org.ua/ (даma звернення: 20.08.2020).

9. Про внесення змін до Кримінального та Кримінального процесуального кодексів України щодо виконання рекомендацій, які містяться у шостій доповіді Європейської комісії про стан виконання Україною Плану дій щзодо лібералізації Європейським Союзом візового режиму для України, стосовно удосконалення процедури арешту майна та інституту спецуіальної конфіскації : Закон України від 18 лютого 2016 р. № 1019-VIII / Верховна Рада України. Відомості Верховної Ради. 2016. № 11. Cm. 127. 